\title{
Molecular Biology of Spermatozoa
}

\author{
Fernando J. Peña $(\mathbb{D}$ \\ Laboratory of Equine Reproduction and Equine Spermatology, Veterinary Teaching Hospital, University of \\ Extremadura, 10003 Cáceres, Spain; fjuanpvega@unex.es; Tel.: +34-927-257167; Fax: +34-927-257102
}

Received: 22 April 2020; Accepted: 24 April 2020; Published: 26 April 2020

The spermatozoon is a very special cell; it is generated in the male reproductive tract and has to travel to the female reproductive tract, of another individual, to fertilize an egg. However, through this amazing journey, it has to be able to respond and adapt to dramatically changing environments. The last decade has witnessed huge advances in the understanding of the molecular biology of this particular cell; these findings have provided new clues to understanding male infertility and the impact of reproductive technologies on sperm function. Thus, empirical approaches for sperm conservation are being substituted by approaches based in translational research. As a transcriptionally silent cell, spermatozoa largely depend on post-translational modifications of proteins to regulate their functions. Among these regulatory mechanisms, redox regulation plays a significant role, and the deregulation of redox homeostasis is behind male factor infertility. With the incorporation of "omics", lipidomics, epigenomics, proteomics, and metabolomics, to the study of spermatozoa, knowledge regarding sperm function has grown significantly over the last decade. Developments in image analysis and advanced flow cytometry have also significantly contributed to this advance. The first part of the special issue of the International Journal of Molecular Sciences dedicated to the molecular biology of the spermatozoa has successfully published 11 outstanding papers, three reviews, and nine research articles that, in only one year, have received numerous citations, demonstrating the interest that has been raised in the scientific community. We are in the "omics" era, which provides very potent tools used increasingly in the areas of cell biology and medicine. In the study by Perez-Patiño et al. [1], changes in the proteome during the cryopreservation process of pig spermatozoa were studied. Cryopreservation, a technology widely used in animal breeding and human medicine, altered proteins directly involved in mitochondrial functionality. Spermatozoa are cells that show a high level of compartmentalization. The distribution of integrins that are transmembrane receptors involved in intracellular signaling and cell to cell adhesion was investigated in mouse spermatozoa [2], revealing that they may play specialized roles in sperm-epithelium and sperm-egg interaction. The interaction of the ejaculate with the female endometrium was studied in a porcine model [3]. This study showed that the ejaculate modified gene expression in the endometrium and oviduct, and this was dependent on the sperm fraction considered. The effect of leukemia in sperm biology was studied in a murine model [4], showing that leukemia altered spermatozoa, increasing the spontaneous acrosome reaction, and decreasing the number of pups born. Ethanol is one of the major concerns in public health and is directly linked to numerous forms of cancer and mental problems. In another study published in this Special Issue, the impact of ethanol on Sertoli cells was studied [5]. Capacitation is the process of maturation which spermatozoa undergo in the female genital tract, and new aspects of this mechanism were studied in a murine model showing new roles for $17 \beta$-estradiol in this important mechanism for sperm maturation [6]. Aggressive chemotherapy leads to male infertility, so the development of methods to achieve in vitro spermatogenesis will be of great interest and has been the subject of one of the papers of this Special Issue [7]. Finally, a potential molecular marker of sperm quality is reported in the last research paper published [8], also stressing the importance of post-transcriptional modification of sperm proteins. In addition, three noteworthy reviews were published [9-11], covering interesting topics, including the role of taste receptors and the role of Zinc in sperm biology. A third review 
covered the mechanisms of sperm damage and repair, stressing the main role of spermatozoa as a transporter of DNA.

Conflicts of Interest: The authors declare no conflict of interest

\section{References}

1. Perez-Patino, C.; Barranco, I.; Li, J.; Padilla, L.; Martinez, E.A.; Rodriguez-Martinez, H.; Roca, J.; Parrilla, I. Cryopreservation Differentially Alters the Proteome of Epididymal and Ejaculated Pig Spermatozoa. Int. J. Mol. Sci. 2019, 20, 1791. [CrossRef] [PubMed]

2. Frolikova, M.; Valaskova, E.; Cerny, J.; Lumeau, A.; Sebkova, N.; Palenikova, V.; Sanches-Hernandez, N.; Pohlova, A.; Manaskova-Postlerova, P.; Dvorakova-Hortova, K. Addressing the Compartmentalization of Specific Integrin Heterodimers in Mouse Sperm. Int. J. Mol. Sci. 2019, 20, 1004. [CrossRef] [PubMed]

3. Alvarez-Rodriguez, M.; Atikuzzaman, M.; Venhoranta, H.; Wright, D.; Rodriguez-Martinez, H. Expression of Immune Regulatory Genes in the Porcine Internal Genital Tract Is Differentially Triggered by Spermatozoa and Seminal Plasma. Int. J. Mol. Sci. 2019, 20, 513. [CrossRef] [PubMed]

4. Michailov, Y.; Lunenfeld, E.; Kapilushnik, J.; Friedler, S.; Meese, E.; Huleihel, M. Acute Myeloid Leukemia Affects Mouse Sperm Parameters, Spontaneous Acrosome Reaction, and Fertility Capacity. Int. J. Mol. Sci. 2019, 20, 219. [CrossRef] [PubMed]

5. Horibe, A.; Eid, N.; Ito, Y.; Otsuki, Y.; Kondo, Y. Ethanol-Induced Autophagy in Sertoli Cells Is Specifically Marked at Androgen-Dependent Stages of the Spermatogenic Cycle: Potential Mechanisms and Implications. Int. J. Mol. Sci. 2019, 20, 184. [CrossRef] [PubMed]

6. Bosakova, T.; Tockstein, A.; Sebkova, N.; Simonik, O.; Adamusova, H.; Albrechtova, J.; Albrecht, T.; Bosakova, Z.; Dvorakova-Hortova, K. New Insight into Sperm Capacitation: A Novel Mechanism of 17beta-Estradiol Signalling. Int. J. Mol. Sci. 2018, 19, 4011. [CrossRef] [PubMed]

7. AbuMadighem, A.; Solomon, R.; Stepanovsky, A.; Kapelushnik, J.; Shi, Q.; Meese, E.; Lunenfeld, E.; Huleihel, M. Development of Spermatogenesis In Vitro in Three-Dimensional Culture from Spermatogonial Cells of Busulfan-Treated Immature Mice. Int. J. Mol. Sci. 2018, 19, 3804. [CrossRef] [PubMed]

8. Nygaard, M.B.; Herlihy, A.S.; Jeanneau, C.; Nielsen, J.E.; Bennett, E.P.; Jorgensen, N.; Clausen, H.; Mandel, U.; Rajpert-De Meyts, E.; Almstrup, K. Expression of the O-Glycosylation Enzyme GalNAc-T3 in the Equatorial Segment Correlates with the Quality of Spermatozoa. Int. J. Mol. Sci. 2018, 19, 2949. [CrossRef] [PubMed]

9. Luddi, A.; Governini, L.; Wilmskotter, D.; Gudermann, T.; Boekhoff, I.; Piomboni, P. Taste Receptors: New Players in Sperm Biology. Int. J. Mol. Sci. 2019, 20, 967. [CrossRef] [PubMed]

10. Garcia-Rodriguez, A.; Gosalvez, J.; Agarwal, A.; Roy, R.; Johnston, S. DNA Damage and Repair in Human Reproductive Cells. Int. J. Mol. Sci. 2018, 20, 31. [CrossRef] [PubMed]

11. Kerns, K.; Zigo, M.; Sutovsky, P. Zinc: A Necessary Ion for Mammalian Sperm Fertilization Competency. Int. J. Mol. Sci. 2018, 19, 4097. [CrossRef] [PubMed]

(C) 2020 by the author. Licensee MDPI, Basel, Switzerland. This article is an open access article distributed under the terms and conditions of the Creative Commons Attribution (CC BY) license (http://creativecommons.org/licenses/by/4.0/). 